\title{
Application of laparoscopy in current fertility practice
}

\author{
Rajita S. Jani ${ }^{1 *}$, Devangi S. Munshi ${ }^{1}$, Shashwat K. Jani ${ }^{2}$, Sanjay P. Munshi ${ }^{2}$
}

\author{
${ }^{1}$ Department of Obstetrics \& Gynecology, L.G. Hospital, Maninagar, Ahmedabad, Gujarat, India \\ ${ }^{2}$ Department of Obstetrics \& Gynecology, V.S. General Hospital, Ellisbridge, Ahmedabad, Gujarat, India
}

Received: 22 March 2014

Revised: 28 March 2014

Accepted: 2 April 2014

\section{*Correspondence:}

Dr. Rajita S. Jani,

E-mail: rajita.munshi@gmail.com

(C) 2014 Jani RS et al. This is an open-access article distributed under the terms of the Creative Commons Attribution Non-Commercial License, which permits unrestricted non-commercial use, distribution, and reproduction in any medium, provided the original work is properly cited.

\begin{abstract}
Background: The present study is carried out with the objective of establishing the role of diagnostic and operative laparoscopy as a simple, safe and accurate tool in the evaluation of infertility. The aims of current study were to study the application of laparoscopy in current fertility practice, to evaluate indications for diagnostic laparoscopy for infertility, to study findings of diagnostic laparoscopy and to study various operative procedures performed for correction of infertility.

Methods: This is a prospective study of 50 women undergoing infertility workup in a private hospital from January 2011 to January 2012. All infertile women having primary or secondary infertility were included in the study. Couples having male factor infertility were excluded from the study. Data were collected and analyzed.

Results: Our study is conducted in 50 cases of infertility patients out of which $74 \%$ were primary infertility and $26 \%$ were secondary infertility. Uterine factors were found in $16 \%$ of cases, tubal factors were found in $44 \%$ of cases, ovarian factors were implicated in $30 \%$ of cases out of which majority (12\%) had PCOD. Among the peritoneal factors $(18 \%)$ endometriosis and pelvic adhesions were found in $6 \%$ each. Inspite of thorough laparoscopic evaluation no cause (unexplained infertility) was found in $14 \%$ of cases and hence overall, the pelvic pathology was found in $86 \%$ of cases.

Conclusions: Laparoscopy is the gold standard for diagnosing tubal and peritoneal disease, endometriosis, adhesions and other pelvic pathology, because no other imaging technique provides the same degree of sensitivity and specificity.
\end{abstract}

Keywords: Laparoscopy, Infertility

\section{INTRODUCTION}

The desire to reproduce is an intensely motivating human force. Couples may also experience strong religious, cultural and social pressure to conceive. Infertility is a life crisis for them. The number of couples seeking medical help for infertility is increasing dramatically (from $8 \%$ to $10-15 \%$ ). ${ }^{1,2}$ This problem is compounded by the trend towards delayed child bearing age to achieve socio-economic, educational and professional goals as well as the newer diseases which are seen mostly related to the changes in the lifestyle. ${ }^{6,8,9}$
Today in the era of scientific advancement and technology, newer diagnostic and operative modalities have paved the path for further insight into this problem. Laparoscopy has emerged in recent years as an accurate method of assessing, evaluating and treating infertility. ${ }^{3,4,7}$ Direct visualization of abdominal and pelvic organs in laparoscopy allows the rapid diagnosis to be made in many conditions where clinical examination and less invasive techniques such as ultrasound and hysterosalpingography fail to identify the problem. ${ }^{5,19}$ 
Laparoscopy is the gold standard for diagnosing tuboperitoneal disease, endometriosis and adhesions and because no other imaging technique provides the same degree of sensitivity and specificity. It is also helpful in the diagnosis of uterine and ovarian factors. ${ }^{11,12}$

Thus, in view of all the above revelations, the present study is a humble endeavor to establish the role of diagnostic and operative laparoscopy as a simple, safe and accurate tool in the evaluation of infertility.

\section{Laparoscopy in infertility}

\section{A. Diagnostic laparoscopy in infertility}

Diagnostic laparoscopy is included now as a part of initial work-up for infertility. Common factors are: ${ }^{13,14,17}$

\section{1) Tubal factors}

Tubal testing can be done to find out:

- Tubal patency.

- Tubo-ovarian adhesions which may interfere with tuboovarian function

- Laparoscopic evaluation necessary before constructive surgery.

\section{2) Ovarian factors}

Inferior surface of the ovary can be inspected by flipping it over with grasping forceps or probe for presence of corpus luteum, follicular cyst, microcyst, chocolate cysts, PCOD, adhesions etc.

Ovarian biopsy is indicated in cases of primary or secondary amenorrhoea, anovulation.

\section{3) Uterine factors}

Uterine factors like small corneal myomas or congenital malformations can be diagnosed.

\section{4) Endometriosis}

Endometriosis is one very important cause of unexplained infertility and can be diagnosed in early stages by laparoscopy.

\section{5) Post operatively}

In tubal surgery as in second look puncture to demonstrate tubal patency and, if necessary, to carry out adhesiolysis and minor corrective surgery.

\section{B. Operative laparoscopy in infertility}

Laparoscopy has been used for: $:^{15,16,18}$

- Ovarian drilling
- Fimbrioplasty and salpingostomy

- Ovarian cystectomy

- Myometcomy

- Tubo-ovarian mass

- Resection and ablation of endometriosis

- Adhesiolysis

- Mullerian agenesis

- Salpingo-ovariocyesis

\section{METHODS}

This is a prospective study of 50 women undergoing infertility workup in a private hospital from January 2011 to January 2012.

All infertile women having primary or secondary infertility were included in the study. Couples having male factor infertility were excluded from the study. Data were collected and analyzed.

\section{RESULTS}

A study consisting of 50 infertility patients, both primary and secondary, was undertaken at a private hospital in Ahmedabad from January 2011 to January 2012, to know the role of diagnostic laparoscopy in the evaluation of infertility.

Table 1: Duration of infertility.

\begin{tabular}{|c|c|c|c|c|c|c|}
\hline \multirow{2}{*}{$\begin{array}{l}\text { Duration of } \\
\text { infertility } \\
\text { (Years) }\end{array}$} & \multicolumn{2}{|c|}{ Primary } & \multicolumn{2}{|c|}{ Secondary } & \multicolumn{2}{|c|}{ Total } \\
\hline & No. & $\%$ & No. & $\%$ & No. & $\%$ \\
\hline $1-5$ & 25 & 67.5 & 9 & 69.2 & 34 & 68.0 \\
\hline $6-10$ & 10 & 27.0 & 3 & 23.1 & 13 & 26.0 \\
\hline $11-15$ & 1 & 2.7 & - & - & 1 & 2.0 \\
\hline $16-20$ & 1 & 2.7 & 1 & 7.6 & 2 & 4.0 \\
\hline Total & 37 & 100.0 & 13 & 100.0 & 50 & 100.0 \\
\hline
\end{tabular}

Table 2: Uterine factors in infertility.

\begin{tabular}{|c|c|c|c|c|c|c|}
\hline \multirow{2}{*}{$\begin{array}{l}\text { Uterine } \\
\text { factors }\end{array}$} & \multicolumn{2}{|c|}{$\begin{array}{l}\text { Primary } \\
(n=37)\end{array}$} & \multicolumn{2}{|c|}{$\begin{array}{l}\text { Secondary } \\
(n=13)\end{array}$} & \multicolumn{2}{|c|}{ Total $(\mathrm{n}=50)$} \\
\hline & No. & $\%$ & No. & $\%$ & No. & $\%$ \\
\hline $\begin{array}{l}\text { Hypoplastic } \\
\text { uterus }\end{array}$ & 3 & 8.1 & - & - & 3 & 6.0 \\
\hline $\begin{array}{l}\text { Mullerian } \\
\text { anomalies }\end{array}$ & 2 & 5.4 & - & - & 2 & 4.0 \\
\hline $\begin{array}{l}\text { Fibroid } \\
\text { uterus }\end{array}$ & 1 & 2.7 & 2 & 15.3 & 3 & 6.0 \\
\hline $\begin{array}{l}\text { Endometrial } \\
\text { TB }\end{array}$ & - & - & - & - & - & - \\
\hline Total & 6 & 16.2 & 2 & 15.3 & 8 & 16.0 \\
\hline Inference & \multicolumn{6}{|c|}{$\begin{array}{l}\text { Congenital anomalies (hypoplastic uterus) and } \\
\text { Mullerian anomalies were more commonly seen } \\
\text { in primary infertility. Patients with } p=0.107 \\
\text { whereas acquired causes (fibroid uterus) were } \\
\text { more commonly seen in secondary infertility } \\
\text { patients with } P \text { value }=0.107 \text {. }\end{array}$} \\
\hline
\end{tabular}


In the present study, 37 cases $(74 \%)$ were of primary infertility and 13 cases $(26 \%)$ were of secondary infertility.

In this study, majority of patients of primary infertility belonged to the age group of 21-25 years (51.3\%) and that of secondary infertility to $26-30$ years $(46.15 \%)$.

In this study, uterine factors accounted for $16 \%$ of infertility causes. Mullerian anomalies were found in 2 cases of primary infertility, out of which one had unicornuate uterus and another had sub septate uterus.

Table 3: Tubal factors in infertility.

\begin{tabular}{|lllllll|}
\hline \multirow{2}{*}{ Tulbal factors } & \multicolumn{1}{l}{ Primary } & \multicolumn{3}{l|}{ Secondary } & Total \\
& No. & $\mathbf{\%}$ & No. & $\mathbf{\%}$ & No. & \% \\
\hline B/L tubal block & 5 & 13.5 & 1 & 7.6 & 6 & 12.0 \\
\hline U/L tubal block & 2 & 5.4 & 1 & 7.6 & 3 & 6.0 \\
\hline Peritubal adhesions & 4 & 10.8 & 2 & 15.3 & 8 & 16.0 \\
\hline Hydrosalpinx & 3 & 8.1 & 1 & 7.6 & 4 & 8.0 \\
\hline T.O. mass & 2 & 5.4 & - & - & 2 & 4.0 \\
\hline Delayed spillage & 1 & 2.7 & - & - & 1 & 2.0 \\
\hline Total & 17 & 45.9 & 5 & 38.4 & 22 & 44.0 \\
\hline Inference & $\begin{array}{l}\text { Peritubal adhesions are found in majority of } \\
\text { infertility patients } \\
\text { tubal block. }\end{array}$ & \multicolumn{7}{ll}{ followed } & by bilateral \\
&
\end{tabular}

Table 4: Results of chromopertubation test.

\begin{tabular}{|c|c|c|c|c|c|c|}
\hline \multirow{2}{*}{$\begin{array}{l}\text { Results of } \\
\text { chromopert- } \\
\text { ubation test }\end{array}$} & \multicolumn{2}{|c|}{$\begin{array}{l}\text { Primary } \\
(n=37)\end{array}$} & \multicolumn{2}{|c|}{$\begin{array}{l}\text { Secondary } \\
(\mathrm{n}=13)\end{array}$} & \multicolumn{2}{|c|}{ Total $(\mathrm{n}=50)$} \\
\hline & No. & $\%$ & No. & $\%$ & No. & $\%$ \\
\hline B/L positive & 27 & 72.9 & 10 & 76.9 & 37 & 74.0 \\
\hline $\mathrm{B} / \mathrm{L}$ negative & 5 & 13.5 & 1 & 7.6 & 6 & 12.0 \\
\hline U/L positive & 3 & 8.1 & 2 & 15.3 & 5 & 10.0 \\
\hline $\begin{array}{l}\text { Delayed } \\
\text { spillage }\end{array}$ & 1 & 2.7 & - & - & 1 & 2.0 \\
\hline $\begin{array}{l}\text { Not } \\
\text { perceived }\end{array}$ & 1 & 2.7 & - & - & 1 & 2.0 \\
\hline Total & 37 & 100.0 & 13 & 100.0 & 50 & 100.0 \\
\hline Inference & & of & & 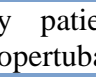 & 5 & \%) had \\
\hline
\end{tabular}

Table 5: Ovarian factors.

\begin{tabular}{|c|c|c|c|c|c|c|}
\hline \multirow{2}{*}{$\begin{array}{l}\text { Ovarian } \\
\text { factors }\end{array}$} & \multicolumn{2}{|c|}{$\begin{array}{l}\text { Primary } \\
(n=37)\end{array}$} & \multicolumn{2}{|c|}{$\begin{array}{l}\text { Secondary } \\
(\mathrm{n}=13)\end{array}$} & \multicolumn{2}{|c|}{ Total $(n=50)$} \\
\hline & No. & $\%$ & No. & $\%$ & No. & $\%$ \\
\hline PCOD & 5 & 13.5 & 1 & 7.7 & 6 & 12.0 \\
\hline $\begin{array}{l}\text { Streak } \\
\text { ovaries }\end{array}$ & 2 & 5.4 & - & - & 2 & 4.0 \\
\hline Ovarian cysts & 2 & 5.4 & 1 & 7.7 & 3 & 6.0 \\
\hline Bald ovaries & 3 & 8.1 & 1 & 7.7 & 4 & 8.0 \\
\hline Total & 12 & 32.4 & 3 & 23.1 & 15 & 30.0 \\
\hline Inference & \multicolumn{6}{|c|}{$\begin{array}{l}\text { Majority of infertility patients had PCOD as an } \\
\text { ovarian factor. }\end{array}$} \\
\hline
\end{tabular}

In present study, ovarian factors accounted for $30 \%$ of cases of infertility in our study. Of the 3 ovarian cysts, one was dermoid cyst, one was chocolate cyst of ovary and the other was simple ovarian cyst.

Table 6: Peritoneal factors in infertility.

\begin{tabular}{|lllllll|}
\hline \multirow{2}{*}{ Peritoneal factors } & \multicolumn{2}{l}{$\begin{array}{l}\text { Primary } \\
(\mathbf{n = 3 7})\end{array}$} & \multicolumn{2}{l}{$\begin{array}{l}\text { Secondary } \\
(\mathbf{n = 1 3})\end{array}$} & \multicolumn{2}{l|}{$\begin{array}{l}\text { Total } \\
(\mathbf{n = 5 0})\end{array}$} \\
\cline { 2 - 7 } & No. & $\mathbf{\%}$ & No. & \% & No. & \% \\
\hline Endometriosis & 2 & 5.4 & 1 & 7.7 & 3 & 6.0 \\
\hline Pelvic adhesions & 2 & 5.4 & 1 & 7.7 & 3 & 6.0 \\
\hline Pelvic infection & 1 & 2.7 & 1 & 7.7 & 2 & 4.0 \\
\hline Pelvic tuberculosis & 1 & 2.7 & - & - & 1 & 2.0 \\
\hline Total & 6 & 16.2 & 3 & 23.1 & 9 & 18 \\
\hline
\end{tabular}

Table 7: Causes of infertility at laparoscopy.

\begin{tabular}{|c|c|c|c|c|c|c|}
\hline \multirow{2}{*}{$\begin{array}{l}\text { Causes of } \\
\text { infertility }\end{array}$} & \multicolumn{2}{|c|}{$\begin{array}{l}\text { Primary } \\
(n=37)\end{array}$} & \multicolumn{2}{|c|}{$\begin{array}{l}\text { Secondary } \\
(\mathrm{n}=13)\end{array}$} & \multicolumn{2}{|c|}{$\begin{array}{l}\text { Total } \\
(\mathbf{n}=50)\end{array}$} \\
\hline & No. & $\%$ & No. & $\%$ & No. & $\%$ \\
\hline Uterine factors & 6 & 16.2 & 2 & 15.3 & 8 & 16 \\
\hline Tubal factors & 17 & 45.9 & 5 & 38.4 & 22 & 44 \\
\hline Ovarian factors & 12 & 32.4 & 3 & 22.8 & 15 & 30 \\
\hline $\begin{array}{l}\text { Peritoneal } \\
\text { factors }\end{array}$ & 6 & 16.2 & 3 & 23.0 & 9 & 18 \\
\hline Unexplained & 5 & 13.5 & 2 & 15.3 & 7 & 14 \\
\hline Total & 46 & 124.2 & 15 & 114.8 & 61 & 122 \\
\hline Inference & \multicolumn{6}{|c|}{$\begin{array}{l}\text { Majority of infertility patients had tubal } \\
\text { factors among the causes }\end{array}$} \\
\hline
\end{tabular}

Table 8: Causes of infertility at laparoscopy in different studies.

\begin{tabular}{|lll|}
\hline \multirow{2}{*}{ Factors } & \multicolumn{2}{l|}{ Study conducted by } \\
\cline { 2 - 3 } & Bhide AG (\%) & Present study (\%) \\
\hline Uterine factors & 20.0 & 16.0 \\
\hline Tubal factors & 42.93 & 44.0 \\
\hline Ovarian factors & 9.7 & 30.0 \\
\hline Peritoneal factors & 10.96 & 18 \\
\hline Unexplained & 27.8 & 14 \\
\hline
\end{tabular}

\section{DISCUSSION}

In Laparoscopy offers the advantage of making a precise diagnosis by direct visualization of the internal genital organs together with ovarian biopsy and chromopertubation, when added onto hysterosalpingography and advanced endocrinological studies, gives necessary armamentarium for diagnosis, treatment and prognosis of the infertile couple.

In recent years, many clinicians have started using laparoscopy as an integral part of the routine assessment of infertile couple. 
Laparoscopy is the gold standard for diagnosing tubal and peritoneal disease, endometriosis, adhesions and other pelvic pathology, because no other imaging technique provides the same degree of sensitivity and specificity.

Laparoscopy has proved of great value in the evaluation of the infertile couple because of low complication rates, conclusive and easy to interpret findings. Hence it is an indispensable diagnostic tool in the evaluation of infertile couples.

\section{Funding: No funding sources}

Conflict of interest: None declared

Ethical approval: Not required

\section{REFERENCES}

1. Leon Speroff. Female infertility. In: Leon Speroff, Marc A. Fritz, eds. Clinical Gynecologic Endocrinology and Infertility. 17th ed. Philadelphia: Lippincott Williams and Wilkins; 2005: 1003-1058.

2. V. G. Padubidri. Pathology of Conception. In: V. G. Padubidri, S. N. Daftary, eds. Shaw: Text book of Gynecology. 14th ed. Noida: Reed Elsevier India Pvt. Ltd; 2008 : 198-199.

3. Gomel V, Taylor PJ. History of laparoscopy. In: Gomel V, Taylor PJ, eds. Diagnostic and Operative Gynecologic Laparoscopy. 1st ed. St. Louis: Mosby Year Book Medical Publishers; 1995 : 46-62

4. Coltart, T. M. Laparoscopy in the diagnosis of tubal patency. BJOG. 1970;77:69-71.

5. Shetty SS, ND Krishna VR. A comparative study of hysterosalpingogram vs. laparoscopy in patients with infertility. J Obstet Gynecol India. 1972;29:511-5.

6. Klinger BE. Evaluation, therapy and outcome in 493 infertile couples. Fertil Steril.1984;4(1):40-6.

7. Chakraborti DK, Kole SK. Diagnostic laparoscopy in gynecologic disorders. J Obstet Gynecol India. 1990;40:262-5.

8. Sharma R, Sharma V. The infertile woman a study of 120 cases. J Indian Med Assoc.1991;82(2):13-32.

9. Fertility Committee of RCOG Gynecological Laparoscopy. The report of the World party of the confidential enquiry into gynecological laparoscopy.
Fertility Committee of RCOG Gynaecological Laparoscopy. 1992:126.

10. Bhide AG., Nalbanski B, Sirakor M, Georgiev S. Diagnostic laparoscopy in female sterility. Khirugia Softia. 2003;50(3):35-6.

11. Corson SL, Chen A, Gutmann JN. Laparoscopy in the normal infertile patient, a question revisired. J Am Assoc Gynecol Laparo. 2000;7(3):317-24.

12. Kumar P, Dang A. Is Laparoscopy necessary in all infertile patients? J Obstet Gynecol India. 2001;51(2):105-8.

13. Jonathan S. Berek. Operative gynecology. In: Jonathan S. Berek, R. D. Rinehart, P. A. Hillard, Eli Y. Adashi, eds. Novak's Gynecology. 14th ed. Philadelphia: Lippincott Williams and Wilkins; 2007: 973-974, 979-983.

14. Tindal VR. Infertility and Subfertility. In: Tindal VR, eds. Jeffcoates Principles of Gynecology. 7th ed. Butterworth: Heinemann International ed; 2008: 699741.

15. Steptoe PC. Gynecology endoscopy, culdoscopy and laparoscopy in infertility. J Obstet Gynecol Br C Wealth. 1965;72:535.

16. Gomel V, Taylor PJ. Diagnostic laparoscopy in infertility. In: Gomel V, Taylor PJ, eds. Diagnostic and Operative Gynecologic Laparoscopy. 1st ed. St. Louis: Mosby Year Book Medical Publishers; 1995: 466-481.

17. Gomel V, Taylor PJ. Indications and contraindications of diagnostic laparoscopy. In: Gomel V, Taylor PJ, eds. Diagnostic and Operative Gynaecology laparoscopy. 1st ed. St. Louis: Mosby Year Book Medical Publishers; 1995: 241-264.

18. Naz T, Hassan L, Gulmeen, Nighat F, Sultan S. Laparoscopic evaluation in infertility. J Coll Physicians Surg Pak. 2009 Nov;19(11):704-7.

19. Sakar MN, Gul T, Atay AE, Celik Y. Comparison of hysterosalpingography and laparoscopy in the evaluation of infertile women. Saudi Med J. 2008 Sep;29(9):1315-8.

DOI: $10.5455 / 2320-1770 . i j r \operatorname{cog} 20140615$

Cite this article as: Jani RS, Munshi DS, Jani SK, Munshi SP. Application of laparoscopy in current fertility practice. Int J Reprod Contracept Obstet Gynecol 2014;3:362-5. 